Vol 1. No. 4, Oktober 2021 P-ISSN : 2774-8030, e-ISSN : 2774-8030

\title{
PROGRAM ANTI SAMPAH PLASTIK SEBAGAI UPAYA MEWUJUDKAN MADRASAH SEHAT DI MTSN 7 KEDIRI
}

\author{
ISTIQOMAH \\ MTsN 7 KEDIRI \\ e-mail: istiqomahhasyim31@gmail.com
}

\begin{abstract}
ABSTRAK
Masalah kebersihan belum sepenuhnya dapat dikelola dengan baik. Sampah plastik termasuk jenis sampah yang tidak dapat terurai sehingga dapat merusak ekosistem tanah. Sebagian masyarakat belum terbiasa memisahkan sampah kering dan basah, antara sampah organik dan anorganir bahkan belum mempertimbangkan polusi yang ditimbulkan akibat pembakaran sampah plastik.Upaya penanggulangan sampah plastik perlu segera dilakukan melalui berbagai gerakan positif. Salah satu gerakan tersebut adalah melaksanakan program anti sampah plastik sebagai bentuk upaya mewujudkan madrasah sehat. Program madrasah sehat ini sesuai dengan amanat peraturan bersama 4 Kementerian yang ditetapkan pada tanggal 17 Oktober 2014 oleh Menteri Pendidikan dan Kebudayaan, Menteri Kesehatan, Menteri Agama dan Menteri Dalam Negeri Tentang UKS/M. Di tahun 2019 kementerian Agama Propinsi Jawa Timur juga telah mengembangkan program Gerakan Madrasah sehat ( GEMES). Meskipun demikian program madrasah sehat sering terkendala oleh sarana prasana yang kurang memadahi sehingga ada indikasi berbagai kurangnya perhatian terhadap sarana/ prasarana, pengetahuan, sikap peserta didik dibidang kesehatan, kantin madrasah, makanan, kesehatan pribadi dan sebagainya.Untuk itu pembiasaan-pembiasaan baru perlu diciptakan agar peran madrasah tidak hanya mendidik secaara ilmiah saja tapi diharapkan juga mampu mendidik karakteristik peserta didik melalui pembiasaan-pembiasaan positif dalam rangka mewujudkan madrasah sehat melalui gerakan program anti sampah plastik.
\end{abstract}

Kata Kunci: Anti sampah plastik, Madrasah sehat

\section{PENDAHULUAN}

Dibanyak tempat masalah kebersihan belum sepenuhnya dapat dikelola dengan baik. Masih banyak ditemui sampah yang tidak dipisahkan antara sampah kering dan basah, antara sampah organik dan anorganik. Bahkan masih banyak pula ditemui sebagian masyarakat yang membakar sampah tanpa mempertimbangkan efek polusi yang ditimbulkan oleh proses pembakaran sampah yang tidak benar, terutama pada sampah plastik. Sebagaimana diketahui bahwa sampah plastik sangat berbahaya jika dibakar karena dapat mengganggu pada saluran pernafasan dan jika dibiarkan sampah plastik termasuk jenis sampah yang tidak dapat terurai sehingga akan merusak ekosistem tanah dan pencemaran lingkungan.

Madrasah menjadi bagian penting dari entitas masyarakat sangat strategis untuk melakukan upaya penanggulangan sampah melalui berbagai gerakan positif dan masif untuk mewujudkan madrasah sehat. Dengan menerapkan berbagai langkah strategis tersebut perlu diwujudkan program anti sampah plastik sebagai bentuk upaya mewujudkan madrasah sehat.

Program anti sampah plastik sebagai bentuk upaya mewujudkan madrasah sehat. Program madrasah sehat ini sesuai dengan amanat peraturan bersama 4 Kementerian yang ditetapkan pada tanggal 17 Oktober 2014 oleh Menteri Pendidikan dan Kebudayaan, Menteri Kesehatan, Menteri Agama dan Menteri Dalam Negeri Tentang UKS/M. Di tahun 2019 kementerian Agama Propinsi Jawa Timur juga telah mengembangkan program Gerakan Madrasah sehat ( GEMES).

Perwujudan kegiatan anti sampah plastik telah masuk dalam TRIAS UKS/M yaitu Pendidikan kesehatan, pelayanan kesehatan dan lingkungan madrasah sehat. Pendidikan kesehatan meliputi peningkatan pengetahuan prilaku, sikap dan keterampilan hidup bersih serta pembudayaan pola hidup sehat. Pelayanan kesehatan meliputi penjaringan kesehatan, 
imunisasi, pemeriksan gigi dan mulut, PHBS ( pola Hidup Bersih dan sehat), tes kebugaran jasmani, PSN ( Pemberantasan Sarang Nyamuk) , toga, Kecacingan kantin sehat, gizi, P3K, dan P3P. Lingkungan madrasah sehat meliputi $7 \mathrm{~K}$ ( Keimanan, keamanan,kebersihan, kekeluargaan, kerindangan, kerapihan dan keindahan) dan pemeliharaan lingkunan sehat yang meliputi bebas narkoba, bebas asap rokok, bebas pornografi.

Realita yang terjadi bahwa program madrasah sehat sering terkendala oleh sarana prasana yang kurang memadahi, seperti sanitasi yang kurang, kantin yang kotor dan budaya hidup bersih belum terlaksana. Dari hasil evaluasi dan pengamatan di madrasah ada indikasi berbagai kondisi seperti masih kurangnya perhatian terhadap sarana/ prasarana, pengetahuan, sikap peserta didik dibidang kesehatan, kantin madrasah, makanan, kesehatan pribadi dan sebagainya. Selain itu belum seimbangnya antara usaha pencapaian tujuan UKS/M dengan sasaran upaya kesehatan ditinjau dari cakupan madrasah, peserta didik, mutu penyelenggara, ketenagaan dan sarana/ prasarana. Perilaku hidup bersih dan sehat juga belum mencapai tingkat yang diharapkan, disamping itu ancaman penyakit terhadap peserta didk masih tinggi dengan adanya penyakit endemis dan kekurangan gizi yang ditunjukkan dengan munculnya jumlah peserta didik yang sakit setiap hari di UKS.

Disi lain kurangnya guru mengajar pendidikan kesehatan / guru yang menangani UKS/M serta kader kesehatan madrasah yang perlu dilatih dalam bidang kesehatan. Terbatasnya sarana prasarana UKS/M seperti pengadaan UKS/M kit, ruang UKS/M. Pengadaan media seperti poster, leaflet, dan buku pencataan atau pelaporan serta kurangnya koordinasi dan komitmen dalam pelaksanaan program UKS/M turut menambah deretan kendala dilapangan.

Juniartini, N. L. P. (2020) dalam Jurnal Bali Membangun Bali menyatakan bahwa faktor edukasi dalam pengelolaan sampah penting dilakukan seiring dengan perkembangan, kesadaran untuk menjaga kesehatan dan menanggulangi permasalahan diatas maka program kegiatan membiasakan untuk prilaku hidup bersih dan sehat harus segera direalisasikan. Kegiatan ini tidak hanya melibatkan peserta didik saja namun perlu melibatkan seluruh warga madrasah sebagai upaya pemeliharan dan peningkatan kesehatan secara terus menerus. Pembiasaan-pembiasaan baru perlu diciptakan agar peran madrasah tidak hanya mendidik secaara ilmiah saja tapi juga mampu mendidik karakteristik peserta didik melalui pembiasaan positif yang salah satunya adalah melalui gerakan anti sampah plastik.

\section{METODE PENELITIAN}

Metode penelitian yang diterapkan dalam penelitian menggunakan metode penelitian kualitatif. Dalam penelitian ini bertujuan memahami fenomena yang dialami oleh subjek penelitian (Moloeng, 2007: 6). Oleh karena itu dalam melaksanakan penelitian pada program anti sampah plastik ini peneliti menggunakan jenis penelitian studi kasus dengan tujuan untuk mengkaji objek dalam bentuk kelompok yang dalam hal ini adalah kegiatan atau program yang dilaksanakan dalam lingkup MTsN 7 Kediri. Melalui data deskriptif diharapkan dapat dengan mudah mengungkap fenomena yang terjadi secara jelas baik yang bersifat alamiah maupun rekayasa manusia (Nana Syaodih. 2010). Langkah berikutnya peneliti melakukan pengumpulan data mengingat pengumpulan data merupakan pekerjaan yang sangat penting dalam proses penelitian. Menurut Ibrahim (2015: 79) menyatakan bahwa penelitian dianggap berhasil data dapat dikumpulkan. Sebaliknya, jika data tidak bisa didapatkan atau tidak dapat dikumpulkan, maka penelitian dipandang tidak berhasil alias gagal.

Adapun teknik pengambilan data dalam penelitian ini peneliti menggunakan teknik observasi, studi dokumenter dan wawancara.

1. Teknik observasi

Observasi yaitu kegiatan mengamati dan mencatat secara sistematis fenomenafenomena yang diselidiki (Cholid Narbuko, 2007: 70). Teknis observasi peneliti gunakan untuk melihat secara langsung dan melakukan pencatatan secara sistemik proses pelaksanaan program anti sampah plastik di MTsN 7 Kediri. Adapun fokus 
pengamatan meliputi rencana program, prosedur pelaksanaan dan evaluasi program anti sampah plastik.

2. Studi Dokumenter

Studi dokumenter atau dokumentary study merupakan suatu teknik pengumpulan data dengan menghimpun dan menganalisis dokumen-dokumen, baik dokumen tertulis maupun dokumen tak tulis seperti gambar dan elektronik. Dokumen tersebut dipilih sesuai dengan kajian penelitian (Sukardinata, 2007: 221-222). Oleh karena itu studi dokumenter ini peneliti gunakan untuk menggali data yang bersumber dari dokumen kegiatan dan program yang sudah berjalan pada program anti sampah plastik di MTsN 7 Kediri

3. Wawancara

Pengumpulan data dengan wawancara (interview) adalah cara atau teknik untuk mendapatkan informasi atau data dari interviewer atau informan dengan bentuk komunikasi secara langsung atau face to face, antara interviewer dengan interviewee (Margono, 2010: 158). Dengan demikian teknik wawancara peneliti gunakan untuk menggali data dengan cara tatap muka secara langsung kepada responden. Adapun responden peneliti tetapkan secara acak yang dapat mewakili seluruh responden dari pelaksana program anti sampah plastik di MTsN 7 Kediri.

\section{HASIL DAN PEMBAHASAN}

\section{A. Aspek Teknis Program Madrasah Sehat}

Dengan memperhatikan latar belakang diatas, dapat dipahami bahwa program madrasah sehat lebih baik diterapkan dilembaga pendidikan. Sementara itu dalam lingkup pendidikan, program madrasah sehat merupakan tanggung jawab seluruh warga madrasah yang dipimpin oleh Kepala Madrasah dan dilakasanakan oleh guru serta semua komponen madrasah yang lain. Kebijakan- kebijakan kepala madrasah mempunyai peran penting dalam menentukan kemajuan madrasah, maka untuk mewujudkan madrasah sehat, kepala madrasah harus banyak memberikan fasilitas terkait dengan kegiatan madrasah sehat.

Adapun langkah- langkah aplikatif yang memungkinkan untuk dilakukan pihak madrasah antara lain :

Pertama, Membentuk tim pengembang madrsasah sehat. Tim ini berasal dari guru pembina UKS/M atau yang pernah mengikuti diklat kesehatan. Tim tersebut bertugas merencanakan program madrasah sehat yang sesuai dengan panduan Gerakan Madrasah Sehat ( GEMES). Tim juga bertugas memilih guru sebagai anggota pada tiap pokja madrasah sehat yang nanti sebagai guru pendamping pokja tersebut.

Kedua, Membentuk anggota KKR ( Kader Kesehatan Remaja). Anggota ini adalah peserta didik yang dipilih $10 \%$ dari jumlah siswa keseluruhan di madrasah. $\mathrm{KKr}$ ini bertugas membantu tim pengembang madrasah sehat dalam mewujudkan program TRIAS UKS/M dalam program madrasah sehat. Anggota KKR Ini diseleksi oleh guru yang telah mengikuti diklat pembina UKS/M.

Ketiga Sosialisasi kantin sehat. Kantin sehat adalah kantin yang bebas dari 5P ( pengawet, pewarna, pengenyal, penyedap, pemutih) dan makanan minuman yang kurang bergizi. Untuk mewujudkan kantin sehat maka dilakukan sosialisasi ke para penjual dikantin madrasah. Sosialisasi ini sekaligus menghimbau agar menu makanannya disesuaikan dengan menu sehat, seperti tidak menngunakan pendidngin, makanan yang lebih banyak sayurnya, jajanan yang tidak memakai pemanis. Selain itu pembungkus makana dan minuman diganti dengan tidak memakai plastik lagi dan bahan lainnya serupa plastik. Mencuci semua peralatan makan dan minuman dengan lebih bersih lagi dengan menyabun dan air mengalir.

Keempat, Kerjasama dengan puskesmas. Kerjasama ini dalam bentuk permohonan sebagai pemateri dalam setiam even kesehatan. Menjadi nara sumber kegiatan Matsama 
dalam rangka memberikan sosialisasi pada peserta didik baru mengenai kesehatan, Imunisasi, screning kesehatan dan kesehatan reproduksi remaja.

Kelima, sosialisasi PHBS ( Prilaku Hidup Bersih Dan Sehat) ke siswa. Kegiatan dilakukan di setiap kelas yang di koordinir oleh TIMLAK UKS/M. Selain itu diadakan njuga sosialisasi tentang kewanitan, khususnya mengenai tata cara dalam merawat kebersihan pada saat datang bulan. Poster - poster kesehatan ditambah disetiap kelas dan tempat - tempat terbuka.

Keenam, memilah sampah. Permasalahan sampah merupakan permasalahan yang paling besar dan harus ditangani dengan seriusdi program madrasah sehat ini. Berkaitan dengan itu maka tim madrasah sehat mengadakan sosialisasi pilah sampah keseluruh warga madrasah. Madrasah juga menyediakan tempat sampah sesuai dengan jenisnya.

Ketujuh, melakukan kegiatan komposing. Komposing adalah kegiatan mengolah sampah organik menjadi pupuk cair dan padat yang bisa digunakan untuk pemeliharaan tanaman di madrasah. Kegiatan ini dilakukan oleh pokja komposing yang didampingi oleh guru pembina.

Kedelapan, membudidayakan toga. Toga adalah tanaman obat keluarga. Tanaman dimanfaatkan oleh warga madrasah dan di rawat oleh tim pokja toga.

Kesembilan, menambah keanekaragaman hayati. Taman merupakan ruang hijau yang berfungsi untuk menambah jumlah oksigen di madrasah, sehingga nanti diharapkan udara di madrasah lebih sehat, sejuk dan nyaman yang membuat warga madrasah nyaman dalam kegiatan belajar mengajar.Kegiatan ini bisa diwujudkan dengan menambah taman di tiap depan kelas masing- masing maupun di ruang terbuka lainnya.

Kesepuluh, ikut serta memperingati PHBN dan PHBI yang berkaitan dengan madrasah sehat. Salah satu kegiatan peringatan nasional yang mendukung program madrasah sehat adalah emisi nol. Kegiatan ini dikelola bersama dengan kegiatan adiwiyata. Hari emisi nol adalah hari peringatn dimana semua warga sekolag mengurangi kegiatan yang menghasilkan emisi, salahsatunya dengan tidak memakai kendaraan bermotor dilingkungan madrasah.

Kesebelas, menambah tempat cuci tangan atau wastafel. Menjaga kebersihan diri merupakan satu bentuk usaha mewujudkan madrasah sehat diantaranya memcuci tangan sebelum dan sesuadah makan.

Keduabelas, Menambah kolam ikan untuk mengurangi pertumbuhan jentik - jentik. Pemberantasan sarang nyamuk merupakan usaha mengurangi perkembangbiakan dan penyebaran penyakit yangdiakibatkan oleh nyamuk.

Ketiga belas, lomba kebersihan kelas. Lomba ini diikuti seluruh kelas dimadrasah. Lomba ini meliputi: pilah sampah, mading yang memuat informasi kesehatan, poster kesehatan dan lingkunga kelas yang bersih dan nyaman.

Keempat belas, launching madrasah bebas plastik. Kegiatan ini dilakukan dalam rangka mengurangi sampah plastik yang menjadi permasalahan nasional. Kedepannya diharapkan kegiatan ini dapat mengurangi penggunaan sampah plastik, dimana sampah plastik ini sulit untuk diurai sehingga menumpuk dan menjadi masalah yangserius, baik bagi kebersihan lingkungan maupun kesehatan. Alex.S (2012: 20-22) menyatakan bahwa diantara bentuk kepedulian lingkungan yaitu dengan meneliti barang-barang yang hanya dipakai sekali dan menggantinya dengan barang yang tahan lama dan memastikan hanya memakai barang ramah lingkungan.

\section{B. Aspek penguatan program madrasah sehat}

Program madrasah sehat harus diperkuat dengan melakukan studi banding dan sekaligus harus dipublikasikan ke luar madrasah. Adapun langkah-langkah yang dilakukan dalam penguatan madrasah sehat antara lain:

1. Mengadakan pelatihan-pelatihan khusus untuk anggota KKR, seperti misalnya diklat dasar anggota PMR madrasah, sosialisasi kegiatan bagi anggota UKS dengan mengirimkan perwakilan anggota UKS ke dinas Kesehatan kab. Kediri 
2. Mengirimkan perwakilan anggota UKS untuk mengikuti pekatihan PSN (pemberantasan sarang nyamuk), dan pelatihan P3K di PMI Kab. Kediri

3. Mengikuti lomba-lomba seperti JAMBORE UKS di tingkat kabupaten

4. Mengunjungi tempat daur ulang dan pengolahan sampah/BANK Sampah di kec. Kepung dalam rangka studi banding untuk diterapkan di madrasah

5. Ikut serta dalam event duta kesehatan remaja tingkat kabupaten

6. Mengunjungi event Pekan Budaya di SLG untuk menambah wawasan kesehatan lingkungan bersama DLH Kab. Kediri

7. Mengadakan bimbingan teknis ke lembaga lain dalam rangka mensosialisasikan madrasah sehat dan madrasah anti plastik

8. Menghadiri event pelatihan pembuatan ecobrick di DLH Kab. Kediri

\section{Realisasi program madrasah sehat}

Program madrasah sehat telah melakukan beberapa realisasi kegiatan yang telah dimulai dari tahun 2016 sampai saat ini masih dikembangkan. Tentunya ada beberapa hal yang masih belum sempurna, namun semua yang terlibat dalam kegiatan ini sudah memberikan yang terbaik untuk membangun program Madrasah Sehat ini agar bisa segera terwujud.

Program-program yang sudah terealisasikan tentunya berkat kerjasama dari semua guru, karyawan dan semua peserta didik MTsN 7 Kediri beserta para jajaran Komite. Selain itu kami juga melibatkan peran serta orang tua peserta didik untuk ikut mensukseskan dan menularkan program Madrasah Sehat anti sampah plastik.

Berikut ini adalah beberapa hasil yang sduah dicapai dalam program Madrasah Sehat MTsN 7 Kediri:

1. Terciptanya suasana Madrasah Sehat di lingkungan MTsN 7 Kediri

suasana nyaman dan rindang bisa dirasakan mulai gerbang masuk hingga ke halaman belakang. Jika dibandingkan dengan suasana madrasah sebelum ada program Madrasah ini, akan terlihat jauh lebih rindang dan nyaman berkat adanya ruang hijau terbuka, terasa tidak panas lagi.

Semua ini berkat kerjasama semua warga MTsN 7 Kediri yang terbentuk dalam tim POKJA-POKJA Madrasah Sehat. Tim POKJA Madrasah Sehat ini terdiri dari guru pendamping dan peserta didik yang dipilih di tiap kelas. Salah satu kegiatan tim POKJA ini adalah kegiatan Jumat Bersih secara bergantian setiap minggunya untuk setiap jenjang. Semua POKJA bekerja sesuai program kerja masing-masing. Misalnya POKJA TOGA, setiap Jumat Bersih mereka akan merawat tanaman yang ada di Taman TOGA MTsN 7 Kediri. Untuk setiap harinya juga dibuat jadwal piket perawatan TOGA. Misalnya dengan menyirami, mengecek pot yang rusak, membersihkan hama tanaman yang ada dan sebagainya.

2. Terbentuknya Tim KKR MTsN 7 Kediri

KKR adalah kader kesehatan remaja yang diambil dari $10 \%$ peserta didik. KKR ini bertugas membantu terwujudnya program-program madrasah sehat seperti penyuluhan kesetahan di tiap kelas tentang PHBS (pendidikan hidup bersih dan sehat). Selain itu KKR juga membantu pada saat program screening yang dilaksanakan oleh PUSKESMAS di MTsN 7 Kediri.

Tugas KKR yang lain adalah membantu tim kesehatan setiap upacara bendera dilaksanakan baik itu di lingkungan madrasah maupun luar madrasah. Mereka adalan peserta didik yang sudah terlatih untuk menangani pertolongan pertama. Prosedur pemilihan anggota KKR adalah dengan melalui seleksi perwakilan di tiap kelas yang nantinya akan terpilih 4 peserta didika yang akan dilatih menjadi tim KKR MTsN 7 Kediri. 
Selama mereka menjadi tim KKR, mereka tidak hanya menjalankan tugas saja, namun juga mendapatkan pelatihan kesehatan baik di tingkat kecamatan maupun di tingkat kabupaten.

3. Terealisasinya Kantin Sehat

Salah satu program Madrasah Sehat adalah membiasakan hidup sehat termasuk juga dengan konsumsi makanan dan minuman yang sehat. Untuk mewujudkannya maka dibuatlah kantin yang lebih memperhatikan nilai-nilai kesehatan dan gizi yang kemudian disebut dengan Kantin Sehat.

Kantin MTsN 7 Kediri awalnya menjual berbagai makanan dan minuman serta jajanan kemasan plastik dan berbagai perasa, pewarna dan pemanis yang kurang menyehatkan. Hingga awal 2016 tercetuslah untuk merubah perlahan menu makanan yang bisa dikonsumsi peserta didik dengan lebih aman dan menyehatkan. Ini dimulai dengan mengumpulkan para penjaga kantin dan mensosialisasikan tentang makanan, minuman dan jajanan sehat termasuk juga dengan lingkungan kantin yang sehat.

Program tersebut selanjutnya bisa terealisasi bertahap di awal tahun pelajaran 2017-2018. Minuman kemasan sudah tidak diperbolehkan lagi untuk dijual. Bakso yang awalnya memakai saos sudah tidak lagi diperbolehkan. Minuman dingin yang memakai es batu atau minuman dingin juga sudah tidak diperbolehkan lagi.

Selama 1 tahun pelaksanaan program Kantin Sehat ni direalisasikan, ada beberapa hal peraturan yang ditambakan untuk semakin mensukseskan program kantin sehat anti sampah plastik. Berkaitan dengan itu maka mulai tahun ajaran 2018-2019 kantin diwajibkan mengganti wadah makanan yang awalnya memakai bungkus plastik atau sejenisnya, diganti dengan wadah yang lebih ramah lingkungan seperti daun pisang dan koran. Minumana yang dijual yang diperbolehkan hanya teh manis dengan memakai gelas belimbing.

Memang awalnya banyak kendala, akan tetapi karena kerjasama dan sosialisasi yang berkelanjutan akhirnya program ini bisa terlaksana dengan baik. Pada awal tahun pelajaran 2019-2020 program kantin sehat meningkatkan pemenuhann gizi pada menu makanan yang tersedia. Diantaranya setiap penjual di kantin wajib menyediakan menu buah segar dan menambahkan banyak sayuran pada menu jualannya. Jadi sekarang peserta didik dan semua warga madrasah sudah bisa menikmati kesegaran buah tanpa harus beli di luar madrasah.

4. Terjalinnya kerjasama PUSKESMAN Kec. Kepung dengan MTsN 7 Kediri

Kerjasama dengan PUSKESMAS ini sudah terjalin lama sehingga sangat mudah bagi MTsN 7 Kediri untuk mengambangkan program-program Madrasah Sehat. Salah satu diantaranya adalah kegiatan Screening untuk semua peserta didik, imunisasi, dan pemberian vitamin. Selain itu PUSKESMAS juga terlibat dalam kegiatan MATSAMA untuk memberikan sosialisasi PHBS kepada peserta didik yang baru dan juga memberikan sosialisasi. Juga memberikan sosialisasi kesehatan Reproduksi kepada peserta didik kelas 9.

5. Membuat Slogan, Poster dan Tulisan-tulisan Kesehatan di tempat-tempat terbuka

Slogan dan Poster ini dibuat oleh POKJA Poster Madrasah Sehat dan dibimbing oleh guru pendamping. Hasil karya mereka dipasang di sekitar Madrasah terutama di tempat-tempat terbuka untuk memberikan pesan dan informasi kesehatan. Juga sebagai ajakan persuasif untuk menjaga kesehatan dan sebagainya.

Semakin banyak poster kesehatan yang dipasang diharapkan akan menambah kesadaran warga madrasah untuk mewujudkan program madrasah sehat.

6. Terwujudnya Pilah Sampah di MTsN 7 Kediri

Pilah sampah merupakan suatu bentuk kegiatan dimana sampah dibuang dan dipilah berdasarkan jenisnya (Sugiarti, Rara, and Istijabatul Aliyah, 2015). Sampah 
yang akan dipilah nanti dikategorikan ke sampah organik, sampah anorganik dan sampah kertas. Sampah organik meliputi sampah bungkus makanan dari kantin, sisa makanan, tusuk lidi dan sebagainya. Sementara sampah anorganik meliputi sampah sisa bolpoin, penggaris yang rusak dan sebagainya. Untuk sampah kertas akan dikordinir oleh tim POKJA Daur Ulang Sampah kertas dengan cara setiap kelas bisa menjualnya ke BANK Sampah. Untuk sampah dedaunan yang berjatuhan, mengingat ada banyak pohon rindang di MTsN 7 Kediri, akan dimasukkan ke lubang biopori yang nantinya bisa dijadikan pupuk organik oleh POKJA Biopori.

Sampah plastik sudah tidak diperbolehkan di madrasah kami, jika masih ditemukan maka akan dikenai sanksi berupa denda sejumlah uang Rp. 50000 yang serahkan kepada pokja polisi lingkungan yang nantinya digunakan untuk infaq masjid. Peraturan telah disepakati semua warga sekolah untuk menjaga agar tidak ada sampah plastik lagi di madrasah.

7. Terlaksananya Program Komposing

Sisa makanan dari kantin bisa dimanfaatkan menjadi kompos cair dan kompos padat. Proses ini dilaksanakan oleh POKJA Komposing. Komposing merupakan kegiatan yang memanfaatkan sisa-sisa makanan yang dicampur dengan bahan pengurai yang dimasukkan ke dalam tong. Campuran ini didiamkan selama 15 hari hingga terbentulah cairan yang yang disebut dengan MOL dan pupuk padat.

Pupuk ini kemudian dimanfaatkan oleh POKJA Taman untuk memupuk tanaman-tanaman yang ada di lingkungan MTsN 7 Kediri.

8. Terciptanya Taman TOGA Assifa MTsN 7 Kediri

Toga atau tanaman obat keluarga adalah tanaman yang bisa digunakan sebagai obat-obatan untuk pertolongan pertama apabila ada peserta didik yang sakit. Misalnya mimisan, bisa diobati sementara dengan daun sirih. TOGA ini lebih aman digunakan untuk pertolongan pertama jika ada yang mengalami sakit.

Selain sirih, adapun beberapa tanaman lainnya seperti Jahe, Kencur, Kunir, Temulawak, Mahkota Dewa, Cakar Ayam dan sebagainya. Selain sebagai koleksi tanaman toga yang digunakan untuk obat, juga bisa untuk mendidik tim pokja Toga tentang informasi-informasi dan manfaat tanaman tersebut. Sehingga nantinya mereka bisa menularkannya ke teman yang lain dan juga ke keluarganya.

Pemanfaatan hasil TOGA untuk pembuatan jamu dipamerkan pada saat event tertentu. Seperti pada saat kegiatan MILAD. Para anggota KKR membuat dan menjual produk jamu tersebut ke para tamu. Selain untuk menyebarkan pola hidup sehat, terutamana minuman sehat, mereka juga belajar untuk berwirausaha.

9. Bertambah jumlah keanekaragaman hati di lingkungan MTsN 7 Kediri

Keanekaragaman hayati adalah menumbuh kembangkan berbagai jenis tanaman dengan cara menmabha koleksi baik dengan cara vegetatif maupun dengan cara bekerjasama dengan toko tanaman. Tanaman yang telah mati diganti dengan tanaman baru hasil dari pembibitan yang dilakukan oleh POKJA Green House.

Tujuan dari menambah keanekaragaman hayati ini adalah untuk menambah ruang hijau, melestarikan jenis tanaman tertentu, dan juga menambah kesejukan dan keindahan di MTsN 7 Kediri.

10. Terlaksananya kegiatan PHBI dan PBHN yang dikaitkan dengan program Madrasah Sehat

Untuk membantu suksesnya program madrasah sehat maka pada setiap perayaan kegiatan PHBI dan PHBN harus dikaitkan dengan program madrasah sehat. Salah satunyan adalah peringatan hari Emisi Nol pada bulan september 2017. Kegiatan ini diwujudkan dengan jalan santai yang diikutioleh semua warga MTsN 7 Kediri, tidak diperbolehkannya membawa kendaraan bermontor ke lingkungan madrasah, dan donor darah bagi guru. 
Saat emisi nol ini juga diadakan lomba membuat kerajinan dari daur ulang sampah anorganik (bekas botol, bungkus plastik, dsb nya) untuk semua peserta didik. Hasilnya ada berbagai karya daur ulang plastik yang sangat indah dan lebih berdaya guna. Dan semuanya dipamerkan di halaman tengah dan bisa dinikmati oleh semua warga madrasah. Ini diharapkan bisa menularkan kreativitas untuk mendau ulang sampah anorganik yang sulit terurai. Sehingga tidak menumpuk dan merusak lingkungan.

Kegiatan lainnya seperti PHBI isro' mi'roj yang di tahun sebelumnya memakai snack bungkus plastik dirubah menjadi snack dengan bungkus kotak kertas. Hal ini untuk mengurangi penggunaan plastik. Menu jajanan yang disediakan untuk tamu di setiap kegiatan juga mulai dikurangi yang menggunakan bungkus plastik. Untuk minuman juga jika memakai botol atau gelas plastik maka selanjutnya akan dikumpulkan utk dibuat ecobrik

11. Bertambanya jumlah wastafel untuk cuci tangan

Menjaga kebersihan diri adalah penting, terutama bagi peserta didik yang hampir 7 jam berada di lingkungan madrasah dengan berbagai kegiatan pembelajaran baik di dalam maupun di luar kelas. Oleh karena itu wastafel untuk cuci tangan sangat penting. Dulu sudah ada beberapa wastafel yang tersedia dan bisa digunakan. Dan selanjutnya untuk meningkatkan program madrasah sehat, maka jumalah wastafel ditambah lagi.

Keberadaan wastafel yang mudah ditemukan di setiap tempat ini diharapkan membantu meningkatkan kesadaran untuk menjaga kebersihan diri, terutama sebelum dan sesudah makan mereka harus mencuci tangannya.

Sementara itu, sisa air cuci tangan ini tidak serta merta dibuang. Namun dimanfaatkan untuk menyirami tanaman yang berada di depan kelas dan dimanfaatkan juga untuk pemeliharaan kolam ikan yang tersambung di bawah tempat cuci tangan tersebut.

12. Terlaksananya program PSN (pemberantasan sarang nyamuk)

Nyamuk merupakan pembawa bibit penyakit. Maka perlu adanya tindakan pencegahan dan penghambatan pertumbuhan nyamuk. Ini sudah diwujudkan dengan memilih tim JUMANTIK (jurupemantau jentik) di MTsN 7 Kediri. Tim ini dari perwakilan beberapa anak yang dipilih oleh guru UKS dan pendamping yang sudah dilatih oleh PMI Kab.Kediri.

Program ini dilaksanakan dan dilanjutkan oleh tim JUMANTIK MTsN 7 Kediri setiap 2 minggu sekali dengan cara memantau dan memeriksa kebersihan lingkungan yang ada di sekitar madrasah. Tim ini memeriksa apakah ada tempat tertentu yang bisa dijadikan berkembang nya nyamuk, yang kemudian akan segera dilaporkan dan dibersihkan. Jika misalkan ada genangan air, akan langsung ditangani juga.

JUMANTIK ini selain memeriksa di lingkungan madrasah juga melakukan sidak ke rumah warga yang ada di sekitar madrasah dengan radius 500 meter. Ini juga membantu mengurangi dan mencegah persebaran nyamuk, selain untuk mensosialisasikan perduli lingkungan bersih dan sehat ke warga.

13. Launching Madrasah Sehat Anti Sampah Plastik Tahun Pelajaran 2019-2020

Kegiatan ini diawali dengan sosialisasi kepada tim Madrasah sehat yang dilaksanakan di dinas lingkungan hidup Kab. Kediri. Beberapa guru yang mengikuti sosialisasi ini mendapatkan informasi terbaru mengenai pemanfaatan sampah plastik guna mengurangi sampah plastik yang menjadi perhatian besar dalam kerusakan lingkungan. Dan ini terjadi baik di lingkungan darat maupun di laut.

Tim madrasah sehat mendapatkan bimbingan teknik dan pelatihan pembuatan ecobrik. Bimek ecobrik ini kemudian disosialisasikan kembali kepada Bapak/Ibu guru MTsN 7 Kediri yang selanjutnya dilaksanakan bimtek ecobrick 
juga. Pada bimtek ini semua bapak ibu guru masing- masing membuat minimal satu ecobrik, selain itu diambil perwakilan 2 anak siswa setiap kelas untuk mengikuti bimtek ini. Nantinya peserta didik akan membuat ecobrik yang pelaksanaannya di serahkan ke guru prakarya.

Karena di madrasah kami sudah tidak ada lagi sampah plastik maka untuk membuat ecobrik ini guru dan siswa harus mengumpulkan samapah plastih yang ada dirumah. Setelah kegiatan ini berjalan kurang lebih satu bulan maka terkumpullah seitar 300 buah ecobrik dengan ukuran botol $600 \mathrm{ml}$ dengan berat minimal 200 gr. Sehinga jika dikalkulasikan sudah $66 \mathrm{~kg}$ sampah plastik yang bisa dimanfaatkan, ini berarti warga MTsN 7 Kediri membantu mengurangi sampah plastik dilingkungan ( tempat tinggal) .

Ecobrik ini merupakan salah satu solusi yang paling efektif untuk mengurangi sampah plastik yan menumpuk dan menjadi masalah lingkungan. Jika madrasah kami dalam sekali waktu bisa mengurangi $66 \mathrm{Kg}$ sampah plastik maka bisa dibayangkan jika dalam setahun ada berapa kwintal sampah plastik yang berkurang dan bisa menyelamatkan bumi dari kerusakan lingkungan yang diakibatkan dari sampah plastik ini. Belum lagi misalkan siswa yang sudah membuat ecobrik ini menularkan pada teman dan keluarganya maka artinya kegiatan ini bisa menyelamatkan bumi dalam skala nasional. Bisa dibayangkan bagaimana bumi tanpa sampah plastik, tentu masa depan bumi ini akan terselatkan dan lestari.

Adapun program madrsah sehat yang selanjutnya adalah :

- Meningkatkan pemilahan sampah dikelas dan kantor

- Menambah jumlah ecobrik dengan cara mengumpulkan sampah plastik yang masih digunakan dikantor ( sampah ATK)

- Meningkatkan kegiatan bebas sampah plastik dalam setiap kegiatan seperti pada saat rapat, syukuran, PHBI/PHBN Milad dan ekstra kurikuler

- Membuat revisi peraturan tentang kedisiplinan misalnya jika ada yang peserta didik yang melanggar untuk diberi sanksi membuat ecobrik

- Menambah karya inovasi dari ecobrik, seperti membuat tempat duduk, meja, tempat sampah, vas bunga, lampu hias, bangku taman, pagar dan sebagainya

- Mengadakan diseminasi atau bimtek ecobrik ke instansi lain, misalnya target 5 instansi dalam satu tahun

- Mengadakan baksos pemungutan sampah massal ke lingkungan sekitar madrasah

- Akhir tahun pelajaran 2019/2020 madrasah bisa mengurangi $90 \%$ sampah plastik dan memanfaatkannya untuk lingkungan madrasah, serta mengurangi sampah plastik dilingkungan madrasah radius $500 \mathrm{~m}$.

\section{KESIMPULAN}

Dari uraian diatas dapat diambil kesimpulan bahwa program madrasah sehat anti sampah plastik itu sangat penting dalam membantu menyelamatkan bumi. Berikut ini beberapa yang dapat disimpulkan:

1. Mewujudkan SDM yang unggul dan sehat merupakan salah satu tujuan nasional dari pemerintah, ini bisa diwujudkan melalui program madrasah sehat.

2. Madrasah sehat merupakan kelanjutan dari program UKS/M yang bertujuan untuk meningkatkan kinerja dengan program yang lebih baik dalam mewujudkan TRIAS UKS/M.

3. Terbentuknya yang mempunyai wawasan kesehatan yang bisa membantu mensukseskan program madrasah sehat

4. Menciptakan suasana yang lebih nyaman dan menyehatkan bagi warga madrasah untuk kegiatan belajar mengajar. 
5. Sampah yang dihasilkan dari kegiatan pilah sampah menjadi lebih berdaya guna sehingga tidak ada lagi penumpukan sampah.

6. Kesehatan warga madrasah terjamin dengan adanya program madrasah sehat.

7. Peserta didik belajar untuk berwirausaha dan berfikir lebih kreatif sebagai salah satu solusi pemanfaatan lingkungan baik berupa tanaman maupun lingkungan.

8. Terbentuknya peserta didik yang peduli dengan kebersihan diri dan kesehatan melalui program madrasah sehat.

9. Madrasah sehat membantu mengatasi masalah global warming dengan menambah ruang hijau dan mengurangi sampah plastik yang tidak bisa terurai.

10. Memaksimalkan potensi siswa dalam pemanfattan daur ulang sampah plastik

\section{DAFTAR PUSTAKA}

Alex, S. (2012). Sukses Mengolah Sampah Organik Menjadi Pupuk Organik. Yogyakarta: Pustaka Baru Press.

Cholid Narbuko., Abu Achmadi. (2007). Metodologi Penelitian. Jakarta: Bumi Aksara.

Ibrahim. (2015). Metodologi Penelitian Kualitatif Panduan Penelitian Beserta Contoh Proposal Kualitatif. Bandung: Alfabeta.

Juniartini, N. L. P. (2020). Jurnal Bali Membangun Bali (Online) http://ejournal.baliprov.go.id/index.php/jbmb/article/view/106. Diakses tanggal 16 September 2021

Moloeng, J. (2007). Metode Penelitian Kualitatif. Bandung: PT Rosdakarya

Nana Syaodih, Sukmadinata. (2010). Metode Penelitian Pendidikan. Bandung : Remaja Rosdakarya.

News, Metro TV. Indonesia Darurat Sampah Plastik. https://www.youtube.com/watch?v=ggAujyp4OYA, di akses tanggal 3 Oktober 2021. S. Margono. (2010). Metodologi Penelitian Pendidikan. Cet. Ke-8. Jakarta: PT. Rineka Cipta. Sugiarti., Rara., \& Istijabatul Aliyah. (2015). Budaya Pengelolaan Sampah Berbasis Masyarakat Melalui Metode 5R Untuk Mewujudkan Lingkungan Bersih Dan Sehat Di Kabupaten Sukoharjo. Jurnal UNS Cakra Wisata, 16(2): 9-22 